BASINDO : Jurnal Kajian Bahasa, Sastra Indonesia, dan Pembelajarannya

Volume 3 Nomor 1, 2019

Journal homepage : http://journal2.um.ac.id/index.php/basindo

\title{
MORFOFONEMIK DALAM TEKS PIDATO KARANGAN SISWA KELAS XII SMA NEGERI 1 DURENAN
}

\author{
Aghilia Khodijah Al-Muthi'ah, Sumadi* \\ Universitas Negeri Malang, Jalan Semarang 5 Malang
}

\begin{tabular}{|c|c|}
\hline A R T I C L E I N F O & A B S T R A C T \\
\hline $\begin{array}{l}\text { Article history: } \\
\text { Received: } 14 \text { Sep } 2018 \\
\text { Accepted: } 15 \text { Dec } 2018 \\
\text { Published: } 31 \text { May } 2019 \\
\text { Keyword: } \\
\text { morfofonemik, teks pidato }\end{array}$ & $\begin{array}{l}\text { Penelitian ini difokuskan pada morfofonemik dalam teks pidato } \\
\text { karangan siswa kelas XII SMA Negeri } 1 \text { Durenan. Fokus penelitian } \\
\text { dirumuskan dalam tiga sub fokus, yaitu perubahan fonem, } \\
\text { penambahan fonem, dan penghilangan fonem dalam teks pidato } \\
\text { karangan siswa kelas XII SMA Negeri } 1 \text { Durenan. Pendekatan } \\
\text { penelitian ini adalah pendekatan kualitatif. Penelitian ini termasuk } \\
\text { jenis penelitian analisis teks. Hasil penelitian ini menunjukkan } \\
\text { bahwa morfofonemik dalam teks pidato karangan siswa kelas XII } \\
\text { SMA Negeri } 1 \text { Durenan meliputi (1) perubahan fonem, (2) } \\
\text { penambahan fonem, dan (3) penghilangan fonem. Perubahan } \\
\text { fonem pada teks pidato karangan siswa, yaitu perubahan fonem } \\
\text { /N/, perubahan fonem /r/, dan perubahan morfem \{ter-\} dan } \\
\text { \{ber-\}; penambahan fonem pada teks pidato karangan siswa, yaitu } \\
\text { penambahan fonem /ə/, dan penambahan fonem /?/, /w/, dan } \\
\text { /y/; penghilangan fonem pada teks pidato karangan siswa, yaitu } \\
\text { penghilangan fonem /N/. Selain ketiga proses morfofonemik di } \\
\text { atas, ditemukan juga kesalahan morfofonemik. }\end{array}$ \\
\hline
\end{tabular}

Proses morfofonemik yang benar membuat makna kata menjadi tepat dan sesuai dengan kaidahnya. Berdasarkan kenyataan yang ada di sekolah, masih ada siswa yang belum sepenuhnya menguasai penggunaan kata yang ditinjau dari segi morfofonemiknya. Hal ini dapat dilihat dari hasil pekerjaan siswa, baik dalam menulis karangan ataupun dalam kegiatan pembelajaran seharihari. Namun, kesalahan penulisan dan penggunaan kata tidak sepenuhnya berasal dari siswa, bisa jadi kesalahan tersebut berasal dari guru yang ketika dalam mengajar kurang menjelaskan mengenai aspek-apek pembentukan kata yang salah satunya yaitu mengenai proses morfofonemik.

Teks pidato dipilih dalam penelitian ini dikarenakan dalam penyusunan teks pidato harus memperhatikan kejelasan dalam penulisan kata-kata menjadi kalimat dan juga paragraf (Indrayani, 2018; Lubis, 2018). Apabila kata yang digunakan dalam penulisan salah, maka akan mengubah makna kata yang sebenarnya. Selain itu, berdasarkan Kurikulum Tingkat Satuan Pendidikan

\footnotetext{
* Corresponding author.

E-mail addresses: aghiliaku@gmail.com (Aghilia Khodijah Al-Muthi’ah), sumadi@yahoo.com (Sumadi)
}

ISSN : 2579-3799 (Online) - BASINDO : Jurnal Kajian Bahasa, Sastra Indonesia, dan Pembelajarannya is licensed under Creative Commons Attribution-ShareAlike 4.0 International License (http://creativecommons.org/licenses/BY/4.0/). 
(KTSP) 2006, pembelajaran menulis teks pidato merupakan salah satu kompetensi dasar yang harus dicapai oleh siswa SMA/MA secara maksimal. Oleh karena itu, peneliti menganggap proses morfofonemik dalam karangan siswa perlu diteliti lebih lanjut untuk mengetahui seberapa jauh kemampuan siswa pada tingkat kelas XII SMA dalam menerapkan proses dan kaidah morfofonemik pada penggunaan kata dalam sebuah teks.

Penelitian tentang morfofonemik pernah dilakukan sebelumnya oleh Andayani (2001) dan Alexandria (2016). Andayani (2001) meneliti tentang Morfofonemik dalam Wacana Tulis Siswa Kelas VI Sekolah Dasar. "Hasil penelitian tersebut meliputi: (1) ditemukan perubahan fonem $/ \mathrm{N} /$, dan perubahan fonem $/ \mathrm{r} /$. (2) ditemukan penambahan fonem /o/. (3) ditemukan penanggalan fonem /N/ dan penanggalan fonem /r/." Sementara itu, Alexandria (2016) meneliti tentang Proses Morfofonemik Afiksasi dalam Rubrik "Percikan" Majalah Gadis. "Hasil penelitian tersebut meliputi: (1) terdapat 344 kata berafiks yang muncul dalam rubrik "Percikan" majalah Gadis. (2) ditemukan 12 pola morfofonemik. pola morfofonemik tersebut yaitu: prefiks \{ber-\}, prefiks $\{$ di- $\}$, prefiks $\{$ ke- $\}$, prefiks $\{$ meN- $\}$, prefiks $\{$ peN- $\}$, prefiks $\{$ se- $\}$, prefiks $\{$ ter $\}$, sufiks $\{-a n\}$, sufiks $\{-\operatorname{kan}\}$, sufiks $\{-i\}$, sufiks $\{-n y a\}, k o n f i k s\{k e-a n\}$. (3) terdapat 10 proses morfofonemik, yaitu sebagai berikut: proses pemunculan fonem, proses pengekalan fonem, proses pemunculan dan pengekalan fonem, proses pergeseran fonem, proses perubahan dan pergeseran fonem, proses pelesapan fonem, proses peluluhan fonem, proses pemunculan fonem secara historis, proses pemunculan fonem berdasarkan pola bahasa asing, dan proses variasi fonem bahasa sumber."

Penelitian ini memiliki kesamaan dengan penelitian yang dilakukan oleh Andayani dan Alexandria, yaitu penelitian ini sama-sama meneliti proses morfofonemik. Perbedaan penelitian ini dengan milik Andayani dan Alexandria terletak pada fokus dan objek penelitian. Fokus penelitian ini adalah macam proses morfofonemik yang berupa perubahan fonem, penambahan fonem, dan penghilangan fonem dalam teks pidato karangan siswa kelas XII SMA Negeri 1 Durenan, sedangkan objek pelitian Andayani adalah wacana tulis siswa kelas VI Sekolah Dasar. Sedangkan fokus penelitian Alexandria meliputi (1) bagaimana munculnya kata berafiks pada rubrik "Percikan" majalah Gadis, (2) bagaimana pola morfofonemik yang ditemukan dalam kata berafiks pada rubrik "Percikan" majalah Gadis, (3) bagaimana proses morfofonemiknya pada kata berafiks tersebut. Berdasarkan persamaan dan perbedaan tersebut, penelitian ini lebih memfokuskan kajiannya pada perubahan fonem, penambahan fonem, dan penghilangan fonem pada teks pidato karangan siswa kelas XII SMA Negeri 1 Durenan.

\section{METODE}

Penelitian ini dilakukan dengan menggunakan pendekatan kualitatif. Jenis penelitian yang digunakan adalah penelitian analisis teks. Penelitian ini dilakukan di SMA Negeri 1 Durenan. Data penelitian ini adalah kata-kata bentukan morfofonemis yang terdapat dalam karangan siswa. Sumber data penelitian ini berupa teks pidato karangan siswa kelas XII SMA Negeri 1 Durenan yang didapatkan dari guru mata pelajaran Bahasa Indonesia. Tidak semua karangan siswa digunakan sebagai sumber data. Kriteria sumber data yang digunakan adalah yang memiliki identitas lengkap, tulisan dapat terbaca dengan jelas, dan tidak dari hasil menjiplak. Instrumen utama yang digunakan dalam penelitian ini adalah buman instrument yaitu peneliti sendiri, berfungsi sebagai pelaksana yang akan mengumpulkan data, menganalisis, dan sekaligus membuat kesimpulan. Pengetahuan peneliti tentang morfofonemik menjadi alat penting dalam penelitian ini. Tahap prosedur pengumpulan data dilakukan melalui empat langkah, yaitu (1) meminta izin kepada guru mata pelajaran Bahasa Indonesia untuk pengambilan data, (2) memperoleh teks pidato langsung dari guru mata pelajaran Bahasa Indonesia, (3) menandai kata-kata bentukan yang mengandung proses morfofonemik, dan (4) menuliskan data yang telah ditemukan. Analisis data pada penelitian ini dilakukan dengan model alir yang diadaptasi dari analisis data kualitatif Miles \& Huberman (dalam Sugiyono, 2013:246). Analisis data kualitatif terdiri dari tiga alur kegiatan. Tiga alur kegiatan tersebut secara berurutan, yaitu reduksi data, penyajian data, dan penarikan kesimpulan. Teknik pengecekan keabsahan data yang dilakukan adalah dengan ketekunan pengamat. Dalam hal tersebut peneliti sebagai pengamat pada penelitian ini memiliki ketekunan dalam membaca, menganalisis dan mengambil kesimpulan sehingga hasil temuannya valid. Selain itu, pengecekan keabsahan data juga 
dilakukan melalui kegiatan konsultasi dengan dosen pembimbing agar data maupun hasil penelitian lebih dapat dipertanggungjawabkan. Tahap-tahap penelitian yang dilakukan adalah persiapan, pelaksanan, dan penyelesaian.

\section{HASIL DAN PEMBAHASAN}

\section{Perubahan Fonem dalam Teks Pidato Karangan Siswa Kelas XII SMA Negeri 1 Durenan}

Perubahan fonem dalam teks pidato karangan siswa kelas XII SMA Negeri 1 Durenan, yaitu (1) perubahan fonem /N/ pada morfem $\{m e N-\},\{m e N-i\}$, dan $\{m e N-k a n\}$, (2) perubahan fonem $/ N /$ pada morfem $\{p e N-\}$ dan $\{p e N-a n\}$, (3) perubahan morfem $\{$ ter $\}$ dan $\{b e r-\}$, (4) perubahan fonem $/ r /$ pada morfem $\{b e r-\}$. Perubahan fonem $/ N /$ pada morfem $\{m e N-\},\{m e N-i\}$, dan $\{m e N-k a n\}$ yang terdapat dalam teks pidato, yaitu mengucapkan, menggantungkan, menghasilkan, memberikan, menjaga, mencegah, mengajar, menjadi, menanam, menjamin, menyelamatkan, membuang, membersibkan, memberi, menuntun, menyenangkan, mendapat, mengingatkan, membiasakan, menyampaikan, mengenai, mendukung, meningkatkan, membantu, mengurangi, mendaur, mengkompos, menciptakan, mengutamakan, menjalankan, menunjang, membuat, mendengar, memahami, membayangkan, menuntut, menerapkan, menggunakan, menjelaskan, menyimpulkan, membawa, menengah, mengendarai, menimbulkan, mengintai, menyepelekan, menyerap, memastikan, menumbubkan, mengadakan, mendatang, mengembangkan, mencapai, memilah, menerima, memberlakukan, mengulangi, mengambil, membentuk, menyadari, menyandang, menyongsong, menyirami, memenubi, mengapa, mengajarkan, memanen, mengenal, membudidayakan, menjadikan, mengamati, menyimpang, memilih, mengobrol, menyadarkan, mengharapkan, mendapatkan, mengerjakan, membuktikan, menginginkan, mendorong, membangun, mencuci, mengingat, mempengarubi, mengajak, menghindari, mencolok, mengganggu, mengotori, dan menambah; perubahan fonem /N/ pada morfem $\{p e N-\}$ dan $\{p e N-a n\}$, yaitu penyakit, penghuni, pembelajaran, penyadaran, pemilihan, pencemaran, pengaturan, pengadaan, penjabaran, penerapan, pembekalan, penghargaan, pencapaian, penyediaan, pemanasan, peningkatan, penghijauan, pembangunan, pengajaran, penyimpangan, penyelamatan, penyampaian, penumpukan, dan penunjang; perubahan morfem $\{$ ter- $\}$ dan $\{$ ber- $\}$, yaitu beserta, bekerja sama, bekerja, dan terawat, dan perubahan fonem $/ r /$ pada morfem $\{$ ber- $\}$, yaitu belajar.

\section{Perubahan Fonem /N/pada Morfem \{meN-\}, \{meN-i\}, dan \{meN-kan\}}

Berdasarkan hasil analisis data, ditemukan perubahan fonem /N/ pada morfem $\{m e N$ \}, $\{m e N-i\}$, dan $\{m e N-k a n\}$ menjadi $/ n /,|m /,| \tilde{n} /$, dan $/ \eta /$. Perubahan tersebut terjadi karena bertemunya morfem $\{m e N-\},\{m e N-i\}$, dan $\{m e N-k a n\}$ dengan bentuk dasar yang berawalan dengan fonem tertentu. Berikut merupakan contoh kalimat yang menunjukkan perubahan fonem $/ N /$ menjadi $/ n /, / m /, / \tilde{n} /$, dan $/ \eta /$ pada morfem $\{m e N-\}$, $\{m e N-i\}$, dan $\{m e N-k a n\}$.

(1) Program ini penting untuk dilaksanakan karena program ini mendukung usaha-usaha pelestarian lingkungan guna meningkatkan kualitas lingkungan. (P2/Prb/03)

(2) Salah satu cara agar lingkungan tidak memberikan bencana adalah menjaga kebersihan lingkungan. (P1/Prb/05)

(3) Hadirin yang terhormat dengan adanya program adiwiyata diharapkan seluruh masyarakat sekolah dapat menyadari bahwa lingkungan yang dan bersih adalah lingkungan yang sehat bagi tubuh kita. (P12/Prb/15)

(4) Kita sebagai penghuni sekolah ini juga terkena dampak positifnya kegiatan belajar mengajar menjadi nyaman karena lingkungan sekolah kita bersih. (P1/Prb/12)

Pada kalimat (1) perubahan fonem /N/ terdapat pada kata mendukung, yaitu berubahnya fonem $/ N /$ menjadi $/ n /$. Perubahan tersebut terjadi karena fonem $/ N /$ pada morfem $\{m e N-\}$ bertemu dengan bentuk dasar yang berawal dengan fonem $/ d /$ pada bentuk dasar $\{d u k u n g\}$. Proses perubahan tersebut dapat dijabarkan sebagai berikut, $\{m e N-\}+\{d u k u n g\}=\{$ mendukung $\}$. Hal ini sesuai dengan pendapat Sumadi (2015:148) yang menyatakan bahwa fonem /N/ pada afiks $\{m e N-\},\{m e N-i\}$, dan $\{m e N-k a n\}$ akan berubah menjadi $/ n /$ apabila bertemu dengan bentuk dasar yang berawal dengan fonem $/ t /, / d /$, dan $/ s y /$. 
Perubahan fonem $/ \mathrm{N} /$ menjadi $/ \mathrm{m} /$ pada kalimat (2) terdapat pada kata memberikan yang terjadi karena fonem /N/ pada morfem \{meN-kan\} bertemu dengan bentuk dasar yang berawal dengan fonem /b/ pada bentuk dasar $\{$ beri\}. Proses perubahan tersebut dapat dijabarkan sebagai berikut, \{meNkan $\}+\{$ beri $\}=\{$ memberikan $\}$. Hal ini sesuai dengan pendapat Muslich (2008:42) yang menyatakan babwa fonem /N/ pada morfem afiks $\{m e N-\}$ dan $\{p e N-\}$ akan berubah menjadi / $/$ apabila bentuk dasar yang mengikutinya berawal dengan fonem $\mid \mathrm{p} /, \mathrm{b} /$, dan $\mid \mathrm{fl}$.

Menurut Ramlan (1985:83), fonem / N/ pada morfem $\{m e N-\}$ dan $\{p e N-\}$ akan berubah menjadi fonem / $/$ /, jika bertemu dengan morfem-morfem yang diawali dengan fonem $/ s, \hat{s}, c$, dan $j /$. Pendapat tersebut sesuai dengan perubahan fonem /N/ pada kalimat (3) pada kata menyadari menjadi / ñ/ yang terjadi karena fonem /N/ pada morfem $\{m e N-i\}$ bertemu dengan bentuk dasar yang berawal dengan fonem / $/$ / pada bentuk. dasar $\{$ sadar $\}$. Proses perubahan tersebut dapat dijabarkan sebagai berikut, $\{m e N-i\}+\{$ sadar $\}=$ $\{$ menyadari $\}$ [mañadari].

Perubahan fonem /N/ pada kalimat (4) terdapat pada kata mengajar, yaitu berubahnya fonem /N/ menjadi / $\mathrm{\eta} /$. Perubahan tersebut terjadi karena fonem /N/ pada morfem $\{m e N-\}$ bertemu dengan bentuk. dasaryang berawal dengan fonem vokal yaitu fonem / a/ pada bentuk dasar \{ajar\}. Proses perubahan tersebut dapat dijabarkan sebagai berikut, $\{$ meN-an $\}+\{$ ajar $\}=\{$ mengajar $\}[$ mangajar $]$. Hal ini sesuai dengan pendapat Tarigan (2009:45) yang menyatakan bahwa morfem \{meN-\} berubah menjadi \{meng-\} apabila diikuti oleh dasar kata yang berfonem awal $/ g, h, k, x$, vokal/.

\section{Perubahan fonem /N/pada Morfem \{peN-\} dan \{peN-an\}}

Perubahan fonem /N/ pada morfem $\{p e N-\}$ dan $\{p e N-a n\}$ muncul dengan perubahan yang beragam. Perubahan fonem /N/ pada morfem $\{p e N-\}$ dan $\{p e N-$ an $\}$ muncul dengan perubahan menjadi $|\eta /,| \tilde{n} /, \mid n /$, dan $/ m /$. Perubahan tersebut terjadi karena bertemunya morfem $\{p e N-\}$ dan $\{p e N-a n\}$ dengan bentuk dasar yang berawalan dengan fonem tertentu. Berikut merupakan contoh kalimat yang menunjukkan perubahan fonem $/ N /$ menjadi $/ \eta /, / \tilde{n} /, / n /$, dan $/ m /$ pada morfem $\{p e N$ \} dan $\{p e N-a n\}$.

(5) Kita sebagai penghuni sekolah ini juga terkena dampak positifnya yaitu kegiatan belajar mengajar menjadi nyaman karena lingkungan sekolah kita bersih. (P1/Prb/10)

(6) Sehat itu berarti tubuh kita dalam keadaan fit, tidak sakit, maupun tidak sedang terjangkit virus penyakit. (P30/Prb/01)

(7) Kemudahan dalam mendapatkan makanan sehat dan berkualitas di kantin, serta perlengkapan penunjang pola hidup bersih dan sehat seperti sabun cuci tangan dan antiseptic gel. (P30/Prb/08)

(8) Manfaat tersebut juga secara tidak langsung menjelaskan bahwa konsep adiwiyata juga dapat dijadikan alat pembelajaran bagi siswa. (P6/Prb/15)

Pada kalimat (5) perubahan fonem / $N /$ pada kata penghuni menjadi / $\eta$ / terjadi karena fonem /N/ pada morfem $\{p e N-\}$ bertemu dengan bentuk dasar yang berawal dengan fonem $/ h /$ pada bentuk dasar $\{$ buni $\}$. Proses perubahan tersebut dapat dijabarkan sebagai berikut, $\{$ peN- $\}+\{$ buni $\}=\{$ penghuni $\}$ [paybuni]. Hal ini sesuai dengan pendapat Ramlan (1985:83), yang menjelaskan bahwa fonem $/ N /$ pada morfem $\{m e N-\}$ dan $\{p e N-\}$ akan berubah menjadi fonem $/ \eta /$, jika bertemu dengan morfem-morfem yang diawali dengan fonem $/ k, g$, $k h$, dan $h$ serta vokal/.

Pada kalimat (6) perubahan fonem /N/ pada kata penyakit menjadi / $/$ / terjadi karena fonem /N/ pada morfem $\{p e N-\}$ bertemu dengan bentuk dasar yang berawal dengan fonem $/ \mathrm{s} /$ pada bentuk dasar $\{$ sakit $\}$. Proses perubahan tersebut dapat dijabarkan sebagai berikut, $\{p e N-\}$ $+\{$ sakit $\}=\{$ penyakit $\}$ [pañakit . Perubahan ini sesuai dengan pendapat Muslich (2008:42), yang menyatakan bahwa fonem /N/ pada morfem afiks $\{m e N-\}$ dan $\{p e N-\}$ akan berubah menjadi $\mid \grave{n} /$ apabila bentuk dasar yang mengikutinya berawal dengan fonem $/ s /, / s y /,|c|$, dan $\mid j /$.

Menurut Sumadi (2015:150), fonem /N/ pada afiks $\{p e N-\}$ dan $\{p e N-a n\}$ akan berubah menjadi $/ \mathrm{n} /$ apabila bertemu dengan bentuk dasar yang berawal dengan fonem /t/, /d/, dan /sy/. Pendapat tersebut sesuai dengan perubahan fonem /N/ pada kata penunjang pada kalimat 
(7) yang berubah menjadi / $\mathrm{n} /$ terjadi karena fonem $/ \mathrm{N} /$ pada morfem $\{\mathrm{peN}$ - $\}$ bertemu dengan bentuk dasar yang berawal dengan fonem /t/ pada bentuk dasar \{tunjang\}. Proses perubahan tersebut dapat dijabarkan sebagai berikut, $\{$ peN- $\}+\{$ tunjang $\}=\{$ penunjang $\}$.

Pada kalimat (8) Perubahan fonem /N/ pada kata pembelajaran menjadi $/ \mathrm{m} /$ terjadi karena fonem /N/ pada morfem $\{p e N-\}$ bertemu dengan bentuk dasar yang berawal dengan fonem / $b /$ pada bentuk dasar $\{$ belajar $\}$. Proses perubahan tersebut dapat dijabarkan sebagai berikut, $\{$ peN-an $\}+\{$ belajar $\}=\{$ pembelajaran $\}$. Hal ini sesuai dengan penjelasan Muslich (2008:42) bahwa fonem /N/ pada morfem afiks $\{m e N-\}$ dan $\{p e N-\}$ akan berubah menjadi $/ m /$ apabila bentuk dasar yang mengikutinya berawal dengan fonem $/ p /, / b /$, dan $/ f /$.

\section{Perubahan Morfem \{ter-\} dan \{ber-\}}

Perubahan morfem $\{$ ter- $\}$ dan $\{$ ber- $\}$ menjadi te- dan be- terjadi karena morfem $\{$ ter $\}$ dan $\{b e r-\}$ bertemu dengan bentuk dasar yang berawal dengan fonem $/ r /$ dan bentuk dasar yang suku kata pertamanya diakhiri dengan -er-. Berikut contoh kalimat yang menunjukkan perubahan morfem $\{$ ter $\}$ dan $\{$ ber- $\}$.

(9) Salah satunya adalah dengan menjaga lingkungan sekitar tetap bersih dan terawat. $(\mathrm{P} 30 / \mathrm{Prb} / 03)$

(10) Yang saya hormati Bapak Ibu guru beserta staf. (P1/Prb/01)

Pada kalimat (9) perubahan morfem ter- pada kata terawat menjadi te- terjadi karena morfem \{ter-\} bertemu dengan bentuk dasar yang berawal dengan fonem $/ r /$ pada bentuk dasar rawat. Proses perubahan tersebut dapat dijabarkan sebagai berikut, $\{$ ter- $\}+\{$ rawat $\}=\{$ terawat $\}$. Hal ini sesuai dengan pendapat Sumadi (2015:153) yang menyatakan bahwa morfem \{ter-\} apabila bertemu dengan bentuk dasar yang diawali dengan fonem $/ r /$ akan berubah menjadi te-.

Menurut Sumadi (2015:154), morfem $\{$ ber- $\}$ akan berubah menjadi be-apabila bertemu dengan bentuk dasar yang suku kata pertamanya diakhiri dengan -er. Pendapat tersebut sesuai dengan perubahan morfem ber- menjadi be- pada kata beserta pada kalimat (10) yang terjadi karena morfem \{ber-\} bertemu dengan bentuk dasar yang berawal dengan bentuk dasar yang suku pertamanya diakhiri dengan - er- pada bentuk dasar serta. Proses perubahan tersebut dapat dijabarkan sebagai berikut, $\{$ ber- $\}+\{$ serta $\}=\{$ beserta $\}$.

\section{Perubahan Fonem / $/$ / pada Morfem \{ber-\}}

Berdasarkan hasil analisis data, ditemukan perubahan fonem $/ r /$ pada morfem $\{b e r-\}$ yang terdapat dalam teks pidato karangan siswa kelas XII SMA Negeri 1 Durenan, yaitu belajar. Berdasarkan data di atas, ditemukan perubahan fonem $/ r /$ menjadi $/ l /$. Perubahan tersebut terjadi karena bertemunya morfem \{ber-\} dengan bentuk dasar tertentu. Berikut bukti data yang menunjukkan perubahan fonem $/ r /$ pada morfem $\{b e r-\}$.

(11) Dengan terlaksananya program adiwiyata ini,berarti kita menciptakan suasana belajar secara lebih nyaman dan sama dengan melestarikan lingkungan bumi kita. (P2/Prb/12)

Perubahan fonem $/ r /$ pada kalimat (11) terdapat pada kata belajar, yaitu berubahnya fonem $/ r /$ menjadi $/ l /$. Perubahan tersebut terjadi karena fonem $/ r /$ pada morfem $\{b e r-\}$ bertemu dengan bentuk dasar \{ajar\}. Hal ini sesuai dengan pendapat Tarigan (2009:46) yang menyatakan bahwa morfem $\{$ ber- $\}$ berubah menjadi $\{$ bel- $\}$ apabila diikuti oleh dasar kata ajar.

\section{Penambahan Fonem dalam Teks Pidato Karangan Siswa Kelas XII SMA Negeri 1 Durenan}

Penambahan fonem dalam teks pidato karangan siswa kelas XII SMA Negeri 1 Durenan, yaitu (1) penambahan fonem / / / pada morfem $\{p e N-a n\}$, (2) penambahan fonem / ?/, $/ w /$, dan $/ y /$ pada morfem $\{p e N-a n\}$, \{per-an\}, dan $\{k e-a n\}$. Penambahan fonem $/ \partial /$ pada morfem $\{$ peN-an $\}$ yang terdapat dalam teks pidato, yaitu pengetabuan; penambahan fonem /?/, $/ w /$, dan $/ y /$ pada morfem $\{p e N-a n\}$, \{per-an\}, dan $\{k e-a n\}$, yaitu keadaan, kelamaan, kekeliruan, 
kelestarian, kepedulian, kecintaan, keterjagaan, perencanaan, kerugian, perlombaan, pengbijauan, pengelolaan, perhatian, perkataan, kemajuan, keberadaan, kementerian, pertanyaan, kebersamaan, kesetaraan, kebiasaan, penyampaian dan kekecewaan.

\section{Penambahan fonem /o / pada Morfem \{peN-an\}}

Berdasarkan hasil analisis data, ditemukan penambahan fonem /a/ pada morfem $\{p e N$ an\} yang terdapat dalam teks pidato karangan siswa kelas XII SMA Negeri 1 Durenan, yaitu pengetahuan. Berikut bukti data yang menunjukkan penambahan fonem / / pada morfem $\{$ peNan\}.

(12) Adiwiyata adalah salah satu program dari Kementerian Lingkungan Hidup dalam rangka mendorong terciptanya pengetahuan dan kesadaran warga sekolah dalam upaya pelestarian lingkungan hidup. (P21/Pnb/03)

Penambahan fonem /a/ pada morfem $\{p e N-a n\}$ pada kalimat (12) terdapat pada kata pengetahuan. Penambahan tersebut terjadi karena morfem $\{p e N-a n\}$ bertemu dengan bentuk dasar yang terdiri atas satu suku kata, yaitu bentuk dasar tahu. Hal tersebut sesuai dengan pendapat Sumadi (2015:152) yang menyatakan bahwa morfem $\{m e N-\},\{p e N-\}$, dan $\{p e N-a n\}$ akan mendapatkan tambahan fonem / $/$ apabila bertemu dengan bentuk dasar yang terdiri atas satu suku kata.

\section{Penambahan fonem /?/, /w/, dan /y/pada Morfem \{peN-an\}, \{per-an\}, dan \{ke-an\}}

Penambahan fonem /?/, /w/, dan $/ y /$ pada morfem $\{p e N-a n\}$, \{per-an\}, dan $\{k e-a n\}$ yang terdapat dalam teks pidato karangan siswa kelas XII SMA Negeri 1 Durenan terjadi karena bertemunya morfem tersebut dengan bentuk dasar yang berakhir dengan vokal $/ a /,|i /|, u /, \mid e /$, dan /o/ sebelum -an. Berikut bukti data yang menunjukkan penambahan fonem /?/, /w/, dan $/ y /$ pada morfem $\{p e N-a n\}$, \{per-an\}, dan $\{k e-a n\}$.

(13)Karena atas limpahan rahmat, taufik, dan hidayahNya, kita dapat berkumpul di acara ini dalam keadaan sehat wal afiat. (P30/Pnb/01)

(14)Untuk merindangkan sekolah maka kita harus melakukan penghijauan di lahan kosong sekitar sekolah. (P22/Pnb/06)

(15)Terima kasih atas perhatian yang diberikan dan mohon maaf apabila ada kesalahan dalam perkataan dan perbuatan. (P11/Pnb/04)

Pada kalimat (13) penambahan fonem /?/ pada kata keadaan terjadi akibat bertemunya morfem \{ke-an\} dengan bentuk dasar yang berakhir dengan vokal /a/ sebelum -an, yaitu bentuk dasar $\{a d a\}$. Proses penambahan tersebut dapat dijabarkan sebagai berikut, $\{k e-a n\}+\{a d a\}=$ \{keadaan\} [kaada?an]. Penambahan fonem tersebut sesuai dengan pendapat Sumadi (2015:153) bahwa morfem $\{p e N-a n\}$, \{per-an\}, dan $\{k e-a n\}$ apabila bertemu dengan bentuk dasar yang berakhir dengan vokal / a/ akan menghadirkan /?/ sebelum - an, apabila bertemu dengan bentuk dasar yang berakhir dengan vokal /u/, /o/, atau / aw/ akan menghadirkan / $w /$ sebelum -an, dan apabila bertemu dengan bentuk dasar yang berakhir dengan vokal /i/ akan menghadirkan / $y /$ sebelum -an

Sesuai dengan pendapat di atas, penambahan fonem pada kalimat (14) terdapat pada kata penghijauan terjadi akibat bertemunya morfem \{peN-an\} dengan bentuk dasar yang berakhir dengan vokal /u/ sebelum -an yang menghadirkan fonem /w/, yaitu bentuk dasar $\{$ hijau $\}$. Proses penambahan tersebut dapat dijabarkan sebagai berikut, $\{$ peN-an $\}+\{$ hijau $\}=$ \{penghijauan\} [pəyhijauwan].

Pada kalimat (15) penambahan fonem /y/ pada kata perhatian terjadi akibat morfem \{per-an\} bertemu dengan bentuk dasar yang berakhir dengan huruf vokal /i/ sebelum -an pada bentuk dasar \{hati\}. Proses penambahan fonem tersebut dapat dijabarkan sebagai berikut, $\{$ per-an\} $+\{$ hati $\}=$ \{perhatian $\}$ [pərhatiyan]. Hal ini sesuai dengan pendapat Muslich (2008:45) yang menjelaskan bahwa apabila morfem afiks $\{$ peN-an\}, \{ke-an\}, \{per-an\}, dan $\{$-an\} bertemu dengan bentuk dasar yang berakhir dengan (1) 
vokal /a/, akan terjadi penambahan /?/, (2) berakhir dengan vokal /u/, /o/, dan /au/ akan terjadi penambahan /w/, (3) dan berakhir dengan vokal $/ i /$ dan /ay/ akan terjadi penambahan $/ y /$.

\section{Penghilangan Fonem dalam Teks Pidato Karangan Siswa Kelas XII SMA Negeri 1 Durenan}

Penghilangan fonem dalam teks pidato karangan siswa kelas XII SMA Negeri 1 Durenan, yaitu (1) penghilangan fonem /N/ pada morfem $\{m e N-\},\{m e N-i\}$, dan $\{m e N-$ $k a n\}$, (2) penghilangan fonem /N/ pada morfem $\{p e N-\}$ dan $\{p e N-a n\}$. Penghilangan fonem /N/ pada morfem $\{m e N-\},\{m e N-i\}$, dan $\{m e N-k a n\}$ yang terdapat dalam teks pidato, yaitu melakukan, memiliki, merupakan, melestarikan, memotivasi, melainkan, merasa, memohon, melatih, merusak, melaksanakan, merawat, melimpabkan, melibatkan, mewujudkan, melanggar, mematikan, merindangkan, menikmati, memulai, melihat, melahirkan, dan merokok; penghilangan fonem /N/ pada morfem $\{p e N-\}$ dan $\{p e N-a n\}$, yaitu penilai, perencanaan, pelestarian pemukiman, dan pemanis.

\section{Penghilangan fonem /N/pada morfem \{meN-\}, \{meN-i\}, dan \{meN-kan\}}

Penghilangan fonem $/ N /$ pada morfem $\{m e N-\},\{m e N-i\}$, dan $\{m e N-k a n\}$ yang terdapat dalam teks pidato terjadi karena bertemunya morfem $\{m e N-\},\{m e N-i\}$, dan $\{m e N-$ kan $\}$ dengan bentuk dasar yang berawal dengan fonem $/ l /, / r /, / m /, / n /$, dan $/ w /$. Berikut bukti data yang menunjukkan penghilangan fonem $/ N /$ pada morfem $\{m e N-\},\{m e N-i\}$, dan $\{m e N-k a n\}$.

(16) Tak hanya itu, pengadaan kegiatan senam pagi juga melatih siswa untuk hidup sehat dengan fisik yang bugar. (P6/Phl/01)

(17) Untuk merindangkan sekolah maka kita harus melakukan penghijauan di lahan kosong sekitar sekolah. (P22/Phl/05)

(18) Menanam pohon memiliki sangat banyak manfaat. (P24/Phl/05)

(19) Agar dikemudian hari anak cucu kita bisa menikmati bumi ini. (P22/Phl/07)

(20) Namun, sebagian besar dari kita belum menyadari tanggung jawab kita dalam mewujudkan program ini. (P13/Phl/01)

Pada kalimat (16) penghilangan fonem /N/ pada kata melatib terjadi akibat morfem $\{m e N-\}$ bertemu dengan bentuk dasar yang berawal dengan fonem /l/ pada bentuk dasar latih. Proses penghilangan tersebut dapat dijabarkan sebagai berikut, $\{m e N-\}+\{$ latib $\}=\{$ melatib $\}$. Penghilangan fonem tersebut sesuai dengan pendapat Muslich (2008:46) bahwa fonem /N/ pada morfem afiks $\{m e N-\}$ dan $\{p e N-\}$ akan mengalami penghilangan apabila bertemu dengan bentuk dasar yang berawal dengan fonem $/ l /,|r /|, y /, / w /$, dan $/$ nasal/.

Fonem /N/ pada afiks $\{m e N-\},\{m e N-i\}$, dan $\{m e N-k a n\}$ akan hilang apabila bertemu dengan bentuk dasar yang berawal dengan fonem $/ l /, / r /, / m /, / n /$, dan $/ w /$ (Sumadi, 2015:147). Sesuai dengan pendapat tersebut, penghilangan fonem /N/ pada kalimat (17) yang terdapat pada kata merindangkan terjadi akibat morfem $\{m e N-k a n\}$ bertemu dengan bentuk dasar yang berawal dengan fonem $/ r /$ pada bentuk dasar rindang. Proses penghilangan tersebut dapat dijabarkan sebagai berikut, $\{$ meN-kan $\}+\{$ rindang $\}=\{$ merindangkan $\}$.

Pada kalimat (18) penghilangan fonem / $N$ / terdapat pada kata memiliki terjadi akibat morfem $\{m e N-i\}$ bertemu dengan bentuk dasar yang berawal dengan fonem $/ \mathrm{m} /$ pada bentuk dasar milik. Proses penghilangan tersebut dapat dijabarkan sebagai berikut, $\{m e N-i\}+\{$ milik $\}=$ \{memiliki\}. Hal ini sesuai dengan pendapat Muslich (2008:42) bahwa fonem /N/ pada morfem afiks $\{m e N-\}$ dan $\{p e N-\}$ akan mengalami penghilangan apabila bertemu dengan bentuk dasar yang berawal dengan fonem $/ l /,|r /|, y /, \mid w /$, dan $/$ nasal $/$.

Berdasarkan pendapat Muslich di atas, penghilangan fonem /N/ pada kalimat (19) terdapat pada kata menikmati terjadi akibat morfem $\{m e N-i\}$ bertemu dengan bentuk dasar yang berawal dengan fonem $/ n /$ pada bentuk dasar nikmat. Proses penghilangan tersebut dapat dijabarkan sebagai berikut, $\{m e N-i\}+\{$ nikmat $\}=\{$ menikmati $\}$. Pada kalimat (20) Penghilangan fonem /N/ pada kata mewnjudkan terjadi akibat morfem \{meN-kan\} bertemu dengan bentuk 
dasar yang berawal dengan fonem / $w /$ pada bentuk dasar wujud. Proses penghilangan tersebut dapat dijabarkan sebagai berikut, $\{$ meN-kan $\}+\{$ wrjud $\}=\{$ mewrijudkan $\}$. Hal ini sesuai dengan pendapat Ramlan (1985:83) yang menyatakan bahwa hilangnya fonem / N/ pada morfem $\{m e N$ \} dan $\{p e N-\}$ terjadi sebagai akibat pertemuan morfem $\{m e N-\}$ dan $\{p e N-\}$ dengan bentuk dasar yang berawal dengan fonem $/ l, r, y, w$, dan /nasal/.

\section{Penghilangan Fonem /N/pada Morfem \{peN-\} dan \{peN-an\}}

Penghilangan fonem /N/ pada morfem $\{p e N-\}$ dan $\{p e N-a n\}$ muncul dengan penghilangan yang beragam. Penghilangan fonem /N/ pada morfem $\{p e N-\}$ dan $\{p e N$-an $\}$ terjadi karena bertemu dengan bentuk dasar yang berawal dengan fonem $/ l /, / r /, / m /$, dan $/ n /$. Berikut bukti data yang menunjukkan penghilangan fonem /N/ pada morfem $\{p e N-\}$ dan $\{p e N-$ an\}.

(21) Adiwiyata adalah salah satu program dari Kementerian Lingkungan Hidup dalam rangka mendorong terciptaya pengetahuan dan kesadaran warga sekolah dalam upaya pelestarian lingkungan hidup. (P21/Phl/01)

(22) Dengan nantinya apabila perencanaan ini sukses, maka dijamin sekolah kita akan menjadi sekolah teladan dan dijadikan acuan bagi sekolah menengah atas lainnya. (P7/Phl/01)

(23) Sebaiknya kita menghindari makanan yang mengandung zat-zat berbahaya, seperti pewarna buatan yang mencolok dan pemanis buatan. (P25/Phl/02)

(24) Mirisnya ada fasilitas yang hanya dipasang ketika tim penilai datang. (P29/Phl/06)

Pada kalimat (21) Penghilangan fonem /N/ pada kata pelestarian terjadi karena fonem /N/ pada morfem $\{p e N-a n\}$ bertemu dengan bentuk dasar yang berawal dengan fonem /l/ pada bentuk dasar lestari. Proses penghilangan tersebut dapat dijabarkan sebagai berikut, $\{p e N-$ $a n\}+\{$ lestari $\}=\{$ pelestarian $\}$ [palestariyan]. Hal ini sesuai dengan pendapat Muslich (2008:46) bahwa fonem /N/ pada morfem afiks $\{m e N-\}$ dan $\{p e N-\}$ akan mengalami penghilangan apabila bertemu dengan bentuk dasar yang berawal dengan fonem $/ l /, / r /,|y /|$,$w / , dan$ /nasal/.

Hilangnya fonem $/ N /$ pada morfem $\{m e N-\}$ dan $\{p e N-\}$ terjadi sebagai akibat pertemuan morfem $\{m e N-\}$ dan $\{p e N-\}$ dengan bentuk dasar yang berawal dengan fonem $/ l, r$, $y$, w, dan nasal/ (Ramlan, 1985:83). Berdasarkan pendapat Ramlan tersebut, pada kalimat (22) penghilangan fonem /N/ pada kata perencanaan terjadi karena fonem / N/ pada morfem $\{p e N$ an $\}$ bertemu dengan bentuk dasar yang berawal dengan fonem $/ r /$ pada bentuk dasar rencana. Proses penghilangan tersebut dapat dijabarkan sebagai berikut, $\{$ peN-an $\}+\{$ rencana $\}=$ \{perencanaan\} [parencana?an].

Pada kalimat (23) penghilangan fonem / N/ pada kata pemanis terjadi karena fonem /N/ pada morfem $\{p e N-\}$ bertemu dengan bentuk dasar yang berawal dengan fonem $/ \mathrm{m} /$ pada bentuk dasar manis. Proses penghilangan tersebut dapat dijabarkan sebagai berikut, $\{p e N-\}+$ $\{$ manis $\}=\{$ pemanis $\}$. Sedangkan pada kalimat (24) penghilangan fonem $/ N /$ pada kata penilai terjadi karena fonem /N/ pada morfem $\{p e N-\}$ bertemu dengan bentuk dasar yang berawal dengan fonem $/ n /$ pada bentuk dasar nilai. Proses penghilangan tersebut dapat dijabarkan sebagai berikut, $\{p e N-\}+\{$ nilai $\}=\{$ penilai $\}$. Penghilangan fonem $/ N /$ pada kata penilai dan pemanis di atas sesuai dengan pendapat Sumadi (2015:150) bahwa fonem /N/ pada afiks $\{p e N-\}$ dan $\{p e N-a n\}$ akan hilang apabila bertemu dengan bentuk dasar yang berawal dengan fonem $/ l /$, $|r /|, m /, \mid n /$, dan $/ w /$.

Selain perubahan, penambahan dan penghilangan fonem. Di dalam teks pidato karangan siswa kelas XII SMA Negeri 1 Durenan juga ditemukan kesalahan morfofonemik pada kata pecinta dan mengkompos. Penulisan kata pecinta seharusnya pencinta. Proses pada kata tersebut termasuk dalam perubahan fonem /N/ pada morfem $\{p e N-\}$ apabila bertemu dengan fonem $/ c /$ akan berubah menjadi $/ \tilde{n} /$. Proses perubahan tersebut dapat dijabarkan sebagai berikut $\{p e N-\}+\{$ cinta $\}=\{$ pencinta $\}[$ pañinta $]$. Hal ini sesuai dengan pendapat Muslich (2008:42) 
bahwa fonem /N/ pada morfem afiks $\{m e N-\}$ dan $\{p e N-\}$ akan berubah menjadi / $\check{l} /$ apabila bentuk dasar yang mengikutinya berawal dengan fonem $/ s /, \mid s y /, / c /$, dan $/ j /$.

Penulisan kata mengkompos seharusnya mengompos. Proses pada kata tersebut termasuk dalam perubahan fonem /N/ pada morfem $\{m e N-\}$ apabila bertemu dengan fonem / $/$ / akan berubah menjadi $/ \eta /$. Proses perubahan tersebut dapat dijabarkan sebagai berikut $\{m e N-\}+$ $\{$ kompos $\}=$ \{mengompos $\}$ [mayompos]. Hal ini sesuai dengan pendapat Ramlan (1985:83) bahwa fonem /N/ pada morfem $\{m e N-\}$ dan $\{p e N-\}$ akan berubah menjadi fonem $/ \eta /$, jika bertemu dengan morfem-morfem yang diawali dengan fonem $/ k, g$, $k h$, dan $h$ serta vokal/.

\section{PENUTUP}

\section{Simpulan}

Berdasarkan hasil penelitian dan pembahasan ada empat simpulan terkait dengan penelitian ini. Empat simpulan tersebut disajikan sebagai berikut.

Pertama, perubahan fonem dalam teks pidato karangan siswa kelas XII SMA Negeri 1 Durenan. Berdasarkan hasil analisis data, proses morfofonemik perubahan fonem dalam teks pidato karangan siswa kelas XII SMA Negeri 1 Durenan yang ditemukan, yaitu perubahan fonem $/ N /$ pada morfem $\{m e N-\},\{m e N-i\}$, dan $\{m e N-k a n\}$, perubahan fonem $/ N /$ pada morfem $\{p e N-\}$ dan $\{p e N-a n\}$, perubahan morfem $\{t e r-\}$ dan $\{b e r-\}$, dan perubahan fonem $/ r /$ pada morfem $\{b e r-\}$. Perubahan fonem $/ N /$ pada morfem $\{m e N-\},\{m e N-i\}$, dan $\{m e N-$ kan\}, yaitu mengucapkan, menggantungkan, menghasilkan, memberikan, menjaga, mencegah, mengajar, menjadi, menanam, menjamin, menyelamatkan, membuang, membersibkan, memberi, menuntun, menyenangkan, mendapat, mengingatkan, membiasakan, menyampaikan, mengenai, mendukung, meningkatkan, membantu, mengurangi, mendaur, mengkompos, menciptakan, mengutamakan, menjalankan, menunjang, membuat, mendengar, memahami, membayangkan, menuntut, menerapkan, menggunakan, menjelaskan, menyimpulkan, membawa, menengah, mengendarai, menimbulkan, mengintai, menyepelekan, menyerap, memastikan, menumbubkan, mengadakan, mendatang, mengembangkan, mencapai, memilah, menerima, memberlakukan, mengulangi, mengambil, membentuk, menyadari, menyandang, menyongsong, menyirami, memenubi, mengapa, mengajarkan, memanen, mengenal, membudidayakan, menjadikan, mengamati, menyimpang, memilih, mengobrol, menyadarkan, mengharapkan, mendapatkan,mengerjakan, membuktikan, menginginkan, mendorong,membangun, mencuci, mengingat, mempengarubi, mengajak, menghindari, mencolok, mengganggu, mengotori, dan menambab; perubahan fonem / N/ pada morfem $\{p e N-\}$ dan $\{p e N-a n\}$, yaitu penyakit, penghuni, pembelajaran, penyadaran, pemiliban, pencemaran, pengaturan, pengadaan, penjabaran, penerapan, pembekalan, penghargaan, pencapaian, penyediaan, pemanasan, peningkatan, penghijauan, pembangunan, pengajaran, penyimpangan, penyelamatan, penyampaian, penumpukan, dan penunjang; perubahan morfem $\{$ ter- $\}$ dan $\{$ ber- $\}$, yaitu beserta, bekerja sama, bekerja, dan terawat, serta perubahan fonem $/ r /$ pada morfem $\{$ ber- $\}$, yaitu belajar.

Kedua, proses morfofonemik penambahan fonem dalam teks pidato karangan siswa kelas XII SMA Negeri 1 Durenan. Berdasarkan hasil analisis data, proses morfofonemik penambahan fonem dalam teks pidato karangan siswa kelas XII SMA Negeri 1 Durenan yang ditemukan, yaitu penambahan fonem /o/ pada morfem $\{p e N-a n\}$, dan penambahan fonem / ?/, / w/, dan $/ y /$ pada morfem $\{p e N-a n\}$, $\{p e r-a n\}$, dan $\{k e-a n\}$. Penambahan fonem /a/ pada morfem $\{p e N-$ an\}, yaitu pengetabuan; penambahan fonem $/ ? /, / w /$, dan $/ y /$ pada morfem $\{p e N-a n\}$, \{per-an\}, dan \{ke-an\}, yaitu keadaan, kelamaan, kekeliruan, kelestarian, kepedulian, kecintaan, keterjagaan, perencanaan, kerugian, perlombaan, penghijauan, pengelolaan, perbatian, perkataan, kemajuan, keberadaan, kementerian, pertanyaan, kebersamaan, kesetaraan, kebiasaan, penyampaian dan kekecewaan.

Ketiga, proses morfofonemik penghilangan fonem dalam teks pidato karangan siswa kelas XII SMA Negeri 1 Durenan. Berdasarkan hasil analisis data, proses morfofonemik penghilangan fonem dalam teks pidato karangan siswa kelas XII SMA Negeri 1 Durenan yang ditemukan, yaitu penghilangan fonem $/ N /$ pada morfem $\{m e N-\},\{m e N-i\}$, dan $\{m e N-k a n\}$, dan penghilangan fonem / N/ pada morfem $\{p e N-\}$ dan $\{p e N-a n\}$. Penghilangan fonem /N/pada morfem $\{m e N-\},\{m e N-i\}$, dan $\{$ meN-kan $\}$, yaitu melakukan, memiliki, merupakan, melestarikan, 
memotivasi, melainkan, merasa, memohon, melatih, merusak, melaksanakan, merawat, melimpabkan, melibatkan, mewujudkan, melanggar, mematikan, merindangkan, menikmati, memulai, melihat, melahirkan, dan merokok; penghilangan fonem /N/ pada morfem $\{p e N-\}$ dan $\{p e N-a n\}$, yaitu penilai, perencanaan, pelestarian pemukiman, dan pemanis.

Keempat, berdasarkan hasil analisis data dalam teks pidato karangan siswa kelas XII SMA Negeri 1 Durenan ditemukan kesalahan morfofonemik, yaitu pada kata pecinta dan mengkompos.

\section{Saran}

Berdasarkan hasil penelitian dan pembahasan, terdapat beberapa saran yang dapat diberikan. Pertama, saran ditujukan kepada guru SMA Negeri 1 Durenan. Hasil penelitian ini dapat digunakan sebagai acuan dalam pembelajaran di dalam kelas sebagai upaya memaksimalkan siswa dalam memahami penulisan kata dengan benar karena selama ini masih ada siswa yang belum benar-benar paham. Kedua, saran ditujukan kepada peneliti selanjutnya. Peneliti selanjutnya disarankan untuk melakukan penelitian sejenis dengan variabel yang berbeda serta sumber pustaka yang lebih lengkap. Selain itu, diharapkan penelitian ini dapat digunakan sebagai salah satu acuan atau rujukan dalam melanjutkan penelitian yang sejenis.

\section{DAFTAR RUJUKAN}

Alexandria, R. (2016). Proses Morfofonemik Afiksasi dalam Rubrik "Percikan" Majalah Gadis. Skripsi tidak diterbitkan. Surakarta: FIB UNS.

Andayani, S. (2001). Morfofonemik dalam Wacana Tulis Siswa Kelas VI Sekolah Dasar. Skripsi tidak dterbitkan. Malang: FS UM.

Indrayani, N. (2018). KEMAMPUAN MENULIS TEKS PIDATO BERBAHASA INDONESIA DI SMA NEGERI 3 WAEAPO [The Ability of Writing Indonesian Speech at SMA Negeri 3 Waeapo]. TOTOBUANG, 6(1). Diambil dari http://totobuang.kemdikbud.go.id/jurnal/index.php/totobuang/article/view/73

Lubis, M. S. (2018). STRUKTUR PENULISAN TEKS PIDATO MAHASISWA SEMESTER III PRODI PENDIDIKAN BAHASA DAN SASTRA INDONESIA INSTITUT PENDIDIKAN TAPANULI SELATAN: KAJIAN RETORIKA. JURNAL EDUCATION AND DEVELOPMENT, 4(2), 66-66.

Muslich, M. (2008). Tata Bentuk Bahasa Indonesia Kajian ke Arah Tatabahasa Deskriptif. Jakarta. Bumi Aksara.

Ramlan. (1985). Morfologi: Suatu Tinjauan Deskriptif. Yogyakarta: CV. Karyono.

Sugiyono. 2013. Metode Penelitian Pendidikan Pendekatan Kuantitatif, Kualitatif, dan R\&D. Bandung: Alfabeta.

Sumadi. 2015. Morfologi Bahasa Indonesia. Malang: UM Press. Tarigan, Henry Guntur. 2009. Pengajaran Morfologi. Bandung:Angkasa. 